\title{
MAIN FACTORS FOR THE FORMING OF REPUTATION IN THE PROCESS OF BUILDING A COMPETITIVE ADVANTAGE OF DEVELOPMENT ENTERPRISES - THE RESULTS OF EMPIRICAL RESEARCH
}

The paper analyzes the factors influencing the reputation of development enterprises. The text provides an answer to the question of what factors are important in shaping the reputation in the process of obtaining a competitive advantage for a development company. An analysis of secondary sources verified the results of the empirical research in the form of a panel of experts. The most important factors in building the reputation were distinguished on the basis of expert evaluations. They include: level of the customer service, previous reputation, the credibility of the company, trust in the company, the company's experience, relations with entities of the market environment, relations with subcontractors, safety of the financial situation, payment terms, the price level, unit cost of the production, the quality of work, locations of completed investments, timely delivery, functionality of products, diversity of housing offer, the quality of materials used, the scope and quality guarantee, the recognition of brand of products, brand identification of the enterprise, organizational culture, skills of the management of developer, professionalism of employees. In addition, an analysis has been carried out with a cross-impact method using the MIC-MAC program. The conclusions of the conducted studies allowed to extract a list of the most important factors in forming the reputation in the process of building a competitive advantage by developers There has also been a systematization of factors affecting the reputation of the development enterprises and the factors which the reputation of the development companies is affected by.

Keywords: reputation, competitiveness, development enterprises, a panel of experts, the cross-impact method

\section{INTRODUCTION}

Managing a business in the dynamic environment encourages participants to seek more effective ways to improve their competitiveness. Today it is recognized that being competitive is the primary aim of all economic organizations. Reputation is one of the most important intangible resources, in the process of building a competitive advantage of development enterprises. This is due to the fact that it is closely linked to confidence which these organizations are endowed by the participants of the market. A positive reputation provides a tool for development and economic security of a development company.

The primary purpose of the article is the answer to the question of what factors are crucial in forming the reputation in the process of obtaining a competitive advantage for a

\footnotetext{
${ }^{1}$ Justyna Grześ-Bukłaho, PhD, Bialystok University of Technology, Faculty of Management, Wiejska St. 45A, 15-351 Bialystok, e-mail j.grzes@pb.edu.pl
} 
development enterprise. Particular attention was paid both to the factors affecting the reputation of development companies, but also the factors that are affected by the reputation of a development enterprise.

\section{THEORETICAL ASPECT OF THE NOTION OF REPUTATION}

Reputation is "the general opinion or judgment of the public about a person or thing", Reputation of a company is the general assessment of a unit, made by stakeholders. It is based on direct experiences of stakeholders with the enterprise, communication, symbolism, which provide information about the company and its actions, and also allow for comparison with the actions taken by key competitors Reputation is therefore based on mutual relationships with stakeholders ${ }^{3}$.

A company's reputation affects the behavior of other participants of the market, in particular the activities of customers, competitors, strategic partners, subcontractors or employees. Therefore, it mobilizes all business developers to care about positive relationships with the participants of the market. In this context a feedback should be noted positive relationships with stakeholders contribute to forming a positive reputation in the market. Reputation, associated with a number of attributes, such as: credibility, confidence, responsibility, influences the relationships with the entities of the market: purchasing behavior of customers, ability to find partners for cooperation, the attractiveness of the company as a place of work, a positive attitude of the media, recommendations of banks, any decisions of potential investors. This broad set of benefits, to a large extent influencing the smooth functioning of a company, which justifies the importance to shape and protect the reputation of the company should be noted by all development enterprises.

\section{METHODOLOGY OF THE SURVEY}

A study on the essence and the importance of reputation in the process of shaping a competitive advantage of development companies was carried out in July 2015 with a method of the panel of experts. The survey was directed to selected people associated with the development industry in Podlaskie who are experts in their fields. A group of 10 experts, connected professionally directly or indirectly to the development industry, participated in a panel discussion. Among the experts were:

- representatives of business development -2 people;

- media representatives -2 people;

- owners of real estate agency - 1 person;

- employees of banks / financial analysts - 2 people;

- people from business market - 1 person;

- architects (designers of the housing industry) - 1 person;

- representatives of the scientific community dealing with the issues of construction -1 person.

\footnotetext{
${ }^{2}$ The American Heritage Dictionary of the English Language, Fifth Edition, Houghton Mifflin Harcourt Publishing Company 2016, https://www.ahdictionary.com/word/search.html?q=reputation\&submit. $\mathrm{x}=29$ \&submit. $\mathrm{y}=13$ [access: 12.12 .2016 ].

${ }^{3}$ M. Gotsi, M.A. Wilson, Corporate Reputation: seeking a definition, "Corporate Communitation: An International Journal", vol. 6, no. 1, 2001, p. 29.
} 
The main purpose of the study was to know the opinion of the experts on the essence of the reputation and the factors shaping the reputation of business development in the process of building a competitive advantage.

In the first stage of the research, the experts assessed sources of obtaining the competitive advantage through business development and identified the main factors of building the competitive advantage. Then the experts were asked to evaluate the role of analogous factors in building the reputation for the development enterprises.

Based on the literature review and based on the author's experience with internships in development enterprises, 31 factors were extracted that can contribute the most to building a competitive advantage and building the reputation of the development companies. Isolated factors were systematized in eight areas:

- factors in the area of the enterprise market included: the company's experience, size of the company, perspective for development of the enterprise, the market share and scale of the company's presence in a given market;

- factors in the area of relations included: relations with the participants of the market (customers, suppliers, media, banks, etc.), relations with subcontractors, level of customer service, previous reputation, the credibility of the company, trust in the company, brand identification of the enterprise;

- factors in the area of finances included: safety of the financial situation, high profitability, creditworthiness, unit cost of the production (on sqm. sold surface);

- factors in the area of product included: the recognition of brand of products, the quality of materials used, the quality of work, functionality of products, locations of completed investments, diversity of housing offer, timely delivery, the scope and quality guarantee and the involvement of the consumer by the ability to impact on the product;

- factors in the area of pricing policy included: the price level, payment terms and promotions, discounts;

- factors in the area of human resources included: skills of the management of developers, and also professionalism of employees;

- factors in the area of organizational included: the organizational structure and organizational culture;

- factor in the material area was the state of technical equipment of the company.

\section{AN ASSESSMENT OF THE ROLE OF SELECTED FACTORS IN THE SHAP- ING OF THE REPUTATION OF A DEVELOPMENT ENTERPRISE - THE RE- SULTS OF EMPIRICAL RESEARCH}

The task of each of the experts was to assess the role of each of the above-mentioned factors in building of the reputation of a development enterprise in a scale of 1 to 5 , with 1 meaning an invalid factor, 2 - an unimportant factor, 3 - a factor of average importance, 4 - an important factor, and 5 - a very important factor. The results of the statistical analysis of each of the listed factors was shown in Table 1. 
Table 1. The importance of factors in building the reputation for a development enterprise

\begin{tabular}{|c|c|c|c|c|c|}
\hline Lp. & Factors & $\begin{array}{c}\text { Arithme- } \\
\text { tic me- } \\
\text { aning (x) }\end{array}$ & $\begin{array}{l}\text { Me- } \\
\text { dian } \\
\text { (Me) }\end{array}$ & $\begin{array}{c}\text { Modal } \\
\text { value } \\
\text { (Do) }\end{array}$ & $\begin{array}{c}\text { Standard } \\
\text { deviation } \\
(\mathbf{S x})\end{array}$ \\
\hline 1. & The company's experience & 4,4 & 5 & 5 & 0,7 \\
\hline 2. & Size of the company & 3,2 & 3 & 3 & 0,6 \\
\hline 3. & Perspective for development of the enterprise & 3,6 & 3 & 3 & 0,8 \\
\hline 4. & $\begin{array}{l}\text { The market share and scale of the company's } \\
\text { presence in a given market }\end{array}$ & 3,8 & 4 & 4 & 0,8 \\
\hline 5. & $\begin{array}{l}\text { Relations with the participants of the market (cus- } \\
\text { tomers, suppliers, media, banks, etc.) }\end{array}$ & 4,4 & 5 & 5 & 1,0 \\
\hline 6. & Relations with subcontractors & 4,2 & 4 & 4 & 0,6 \\
\hline 7. & Level of the customer service & 4,7 & 5 & 5 & 0,5 \\
\hline 8. & $\begin{array}{l}\text { Reputation, the credibility of the company (previ- } \\
\text { ous) }\end{array}$ & 4,7 & 5 & 5 & 0,5 \\
\hline 9. & Trust in the the company & 4,5 & 5 & $4 ; 5$ & 0,5 \\
\hline 10. & Brand identification of the enterprise & 4,0 & 4 & 4 & 0,7 \\
\hline 11. & Safety of the financial situation & 4,7 & 5 & 5 & 0,7 \\
\hline 12. & High profitability & 3,6 & 4 & 4 & 0,7 \\
\hline 13. & Creditworthiness & 3,9 & 4 & 4 & 0,7 \\
\hline 14. & Unit cost of the production (on sqm. sold surface) & 4,2 & 4 & $4 ; 5$ & 0,8 \\
\hline 15. & The recognition of brand of products & 4,3 & 4 & 4 & 0,7 \\
\hline 16. & The quality of materials used & 4,1 & 4 & 4 & 0,3 \\
\hline 17. & The quality of work & 4,7 & 5 & 5 & 0,5 \\
\hline 18. & Functionality of products & 4,3 & 4 & 4 & 0,5 \\
\hline 19. & Locations of completed investments & 4,6 & 5 & 5 & 0,5 \\
\hline 20. & Diversity of housing offer & 4,1 & 4 & $4 ; 5$ & 1,0 \\
\hline 21. & Timely delivery & 4,6 & 5 & 5 & 0,5 \\
\hline 22. & The scope and quality guarantee & 4,6 & 5 & 5 & 0,5 \\
\hline 23. & $\begin{array}{l}\text { The involvement of the consumer by the ability to } \\
\text { impact on the proproduct }\end{array}$ & 3,6 & 4 & 4 & 0,5 \\
\hline 24. & The price level & 4,6 & 5 & 5 & 0,7 \\
\hline 25. & Payment terms & 4,3 & 4 & 4 & 0,7 \\
\hline 26. & Promotions, discounts & 3,9 & 4 & 4 & 0,7 \\
\hline 27. & Skills of the management of developer & 4,1 & 4 & 4 & 0,7 \\
\hline 28. & Professionalism of employees & 4,0 & 4 & 4 & 0,7 \\
\hline 29. & The organizational structure & 3,3 & 3 & 3 & 0,9 \\
\hline 30. & Organizational culture & 4,2 & 4 & 4 & 0,6 \\
\hline 31. & The state of technical equipment of the company & 3,0 & 3 & 3 & 0,9 \\
\hline
\end{tabular}

Source: author's own study based on data obtained from the panel of experts $(n=10)$ 
The opinions of experts confirmed the dominating influence of factors in relational area on the forming of the reputation of development enterprises. Moreover, what is characteristic for the development industry, no less important are the factors in the area of product, in the present case - apartments. Therefore, the most important factors in forming the reputation of development enterprises are:

- previous reputation;

- the credibility of the company (average 4,7; median 5);

- level of the customer service (average 4,7; median 5);

- the quality of work (average 4,7; median 5);

- $\quad$ safety of the financial situation (average 4,7; median 5).

Among the factors of the product area, high ratings was obtained by: locations of completed investments (average 4,6; median 5), timely delivery (average 4,6; median 5), the scope and quality guarantee (average 4,6; median 5), and also the recognition of brand of products (average 4,3; median 4), functionality of products (average 4,3; median 4), the quality of materials used (average 4,1 ; median 4 ) and diversity of housing offer (average 4,1 ; median 4).

The factors assessed at most from relational area, beyond the previously indicated, included: trust in the the company (average 4,5; median 5), relations with entities of the market environment - customers, suppliers, media, banks, etc. (average 4,4; median 5), relations with subcontractors (average 4,2; median 4). The experts considered moreover, that on the reputation of the developer companies affected, among other: the company's experience (average 4,4; median 5), the price level (average 4,6; median 5) or payment terms (average 4,3; median 4).

With the lowest assesment similarly as in the case of factors affecting competitive advantage, were factors such as: the state of technical equipment of the company (average 3,0 ), size of the company (average 3,2) and the organizational structure (average 3,3).

The factors assessed definitely higher in the case of forming a reputation than in case of factors affecting the buildinga competitive edge were: organizational culture and the quality of materials used. It is also worthwhile to note that almost all factors were recognised by experts as very important (evaluation 5) or important (evaluation 4) as evidenced by the other statistical measures.

\section{IMPORTANT FACTORS IN THE FORMING OF REPUTATION}

Based on the assessment made by the experts on the importance of specified factors in the forming of reputation of the development companies it was possible to distinguish the key factors in building of reputation.

As the recognized key factors in building of reputation were those that were rated as the least important, that their arithmetic mean was 4,0 and above. This assessment was received for 22 out of 31 analyzed factors. The key factors in building of reputation for development enterprises are therefore::

- level of the customer service;

- previous reputation, the credibility of the company;

- the quality of work;

- safety of the financial situation;

- locations of completed investments;

- timely delivery; 
- the scope and quality guarantee;

- the price level;

- trust in the the company;

- the company's experience;

- relations with entities of the market environment (customers, suppliers, media, banks, etc.);

- the recognition of brand of products;

- functionality of products;

- payment terms;

- relations with subcontractors;

- unit cost of the production (on sqm. sold surface);

- organizational culture;

- the quality of materials used;

- diversity of housing offer;

- skills of the management of developer;

- brand identification of the enterprise;

- professionalism of employees.

\section{THE DISTINCTION OF THE MOST IMPORTANT FACTORS ASSOCIATED WITH A REPUTATION OF A DEVELOPMENT ENTERPRISE - THE RESULTS OF THE ANALYSIS}

Because of the fact that the selected group of the key factors forming the reputation is quite extensive, an attempt to reduce the amount of the most important factors was made. For this purpose, the structural analysis of influence was used, which is one of the methods of organizing and analyzing sets, including a large number of interacting variables. A cross-impact analysis begins with determining the set of factors which can potentially constitute some key variables in a given system. The analyzed factors, trends and events are seemingly unrelated, but the method of cross-impact allows to specify their mutual influence and overlapping relationships between the ${ }^{4}$. The primary purpose of a crossimpact analysis is to identify the variables that influence the behavior of the analyzed system (eg. forming the reputation) the strongest.

As a part of the survey of the panel of experts, a structural analysis was conducted. The first stage of the analysis consisted of making a list of factors affecting the operation of the development enterprises and relationship building with stakeholders. As a result, a list of 18 variables shown in table 2 was developed.

The identification of key variables was conducted using the MIC-MAC program (Impact Matrix Cross - Reference Multiplication Applied to a Classification). As a part of the analyzed factors influencing the reputation of development enterprises and the factors to which the reputation has the strongest impact,a graph was created showing the direct impact of the factors. Figure 1 includes only factors associated with reputation.

\footnotetext{
${ }^{4}$ J.M. Wójcicki, P. Ładyżyński, System monitorowania i scenariusze rozwoju technologii medycznych w Polsce, Konsorcjum ROTMED, Warszawa 2008, p. 197.
} 
Main factors for the forming...

Table 2. Variables and trends for a cross-impact analysis

\begin{tabular}{|l|l|c|}
\hline Lp. & \multicolumn{1}{|c|}{ Name of the factor (long label) } & $\begin{array}{c}\text { Shortcurt } \\
\text { (short label) }\end{array}$ \\
\hline 1. & The company's experience & CZ1 \\
\hline 2. & Good financial condition & CZ2 \\
\hline 3. & Good reputation, the credibility of the company, opinions & CZ3 \\
\hline 4. & Relations with customers/ Level of the customer service & CZ4 \\
\hline 5. & Relations with suppliers and subcontractors & CZ5 \\
\hline 6. & Cooperation with media & CZ6 \\
\hline 7. & Relations with banks & CZ7 \\
\hline 8. & The price level & CZ8 \\
\hline 9. & The quality of work & CZ9 \\
\hline 10. & Timely delivery & CZ10 \\
\hline 11. & Awards and recognitions & CZ11 \\
\hline 12. & Advertising active policy & CZ12 \\
\hline 13. & Social responsibility, charity activities & CZ13 \\
\hline 14. & Name and logo of the company & CZ14 \\
\hline 15. & Commercial materials & CZ15 \\
\hline 16. & Decor of the registered office and office interiors of the company & CZ16 \\
\hline 17. & Participation in fairs / exhibitions & CZ17 \\
\hline 18. & Lobbying in the local environment & CZ18 \\
\hline
\end{tabular}

Source: author's own study using the MIC-MAC program

The results contained on the above graph can be used to group the factors according to their strength of influence on the reputation of development enterprises (Table 3).

Table 3. Factors affecting the reputation of development enterprises

\begin{tabular}{|c|c|c|}
\hline $\begin{array}{l}\text { Factors having } \\
\text { a strong impact } \\
\text { on the reputation }\end{array}$ & $\begin{array}{l}\text { Factors having } \\
\text { a moderate impact } \\
\text { on the reputation }\end{array}$ & $\begin{array}{c}\text { Factors having } \\
\text { a weak impact } \\
\text { on the reputation }\end{array}$ \\
\hline $\begin{array}{l}\text { The company's } \\
\text { experience }\end{array}$ & Good financial condition & Awards and recognitions \\
\hline $\begin{array}{l}\text { Relations with customers/ } \\
\text { Level of the customer service }\end{array}$ & Cooperation with media & Name and logo of the company \\
\hline $\begin{array}{l}\text { Relations with suppliers and } \\
\text { subcontractors }\end{array}$ & Relations with banks & Commercial materials \\
\hline The quality of work & The price level & $\begin{array}{l}\text { Decor of the registered office and } \\
\text { office interiors of the company }\end{array}$ \\
\hline Timely delivery & $\begin{array}{l}\text { Social responsibility, chari- } \\
\text { ty activities }\end{array}$ & Participation in fairs / exhibitions \\
\hline Actieve advertising policy & & $\begin{array}{l}\text { Lobbying in the local environ- } \\
\text { ment }\end{array}$ \\
\hline
\end{tabular}

Source: author's own study based on data obtained from the panel of experts $(n=10)$ 


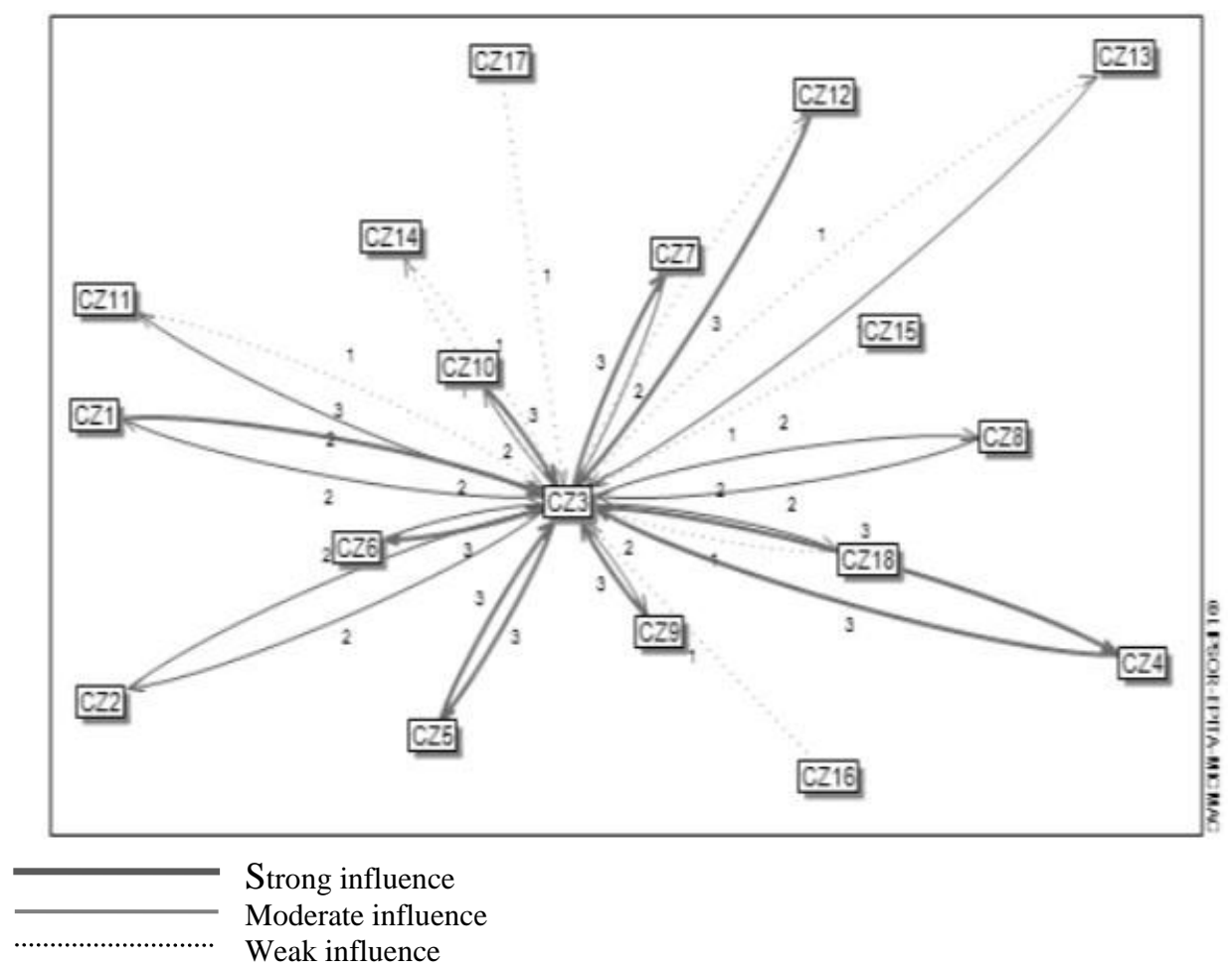

Fig. 1. The graph of direct impacts which includes factors connected to the reputation of development enterpises

Source: author's own study based on data obtained from the panel of experts $(n=10)$ using the MIC-MAC program

The results of the research indicate that the factors influencing the reputation of development companies the strongest are those connected with the relationship with clients, suppliers and subcontractors. Reputation is formed based on the assessment of the quality of work and timely delivery of the investment, it is built with the acquisition of experience by the company, it is also affected by the active advertising policy.

A cooperation with media and banks has a moderate influence on the reputation. These units, due to the carried out policy and gradually built confidence, rarely make a public assessment of their relationship with the market entities, and do not have the biggest impact on the formation of reputation. Factors with an average impact on building the reputation are: a price level, good financial condition of the development enterprise and charity activity conducted by them, as well as social responsibility.

Factors with a small impact on the reputation, affecting the image of the enterprise are: name and logo of the company, decor of the registered office and office interiors of the company, awards and recognitions, commercial materials, participation in fairs / exhibitions, and also lobbying in the local environment.

The data presented in the graph can also be used to group the factors according to the impact on reputation (Table 4). 
Table 4. Factors which are affected by the development enterprises' reputation

\begin{tabular}{|c|c|c|c|}
\hline $\begin{array}{c}\text { Factors that } \\
\text { reputation has } \\
\text { a strong impact on }\end{array}$ & $\begin{array}{c}\text { Factors that } \\
\text { reputation has } \\
\text { a moderate } \\
\text { impact on }\end{array}$ & $\begin{array}{c}\text { Factors that } \\
\text { reputation has } \\
\text { a weak impact on }\end{array}$ & $\begin{array}{l}\text { Factors that } \\
\text { reputation has } \\
\text { no impact on }\end{array}$ \\
\hline $\begin{array}{l}\text { Relations with cus- } \\
\text { tomers/ Level of the } \\
\text { customer service }\end{array}$ & $\begin{array}{l}\text { The company's } \\
\text { experience }\end{array}$ & $\begin{array}{l}\text { Active advertising } \\
\text { policy }\end{array}$ & $\begin{array}{l}\text { Commercial } \\
\text { materials }\end{array}$ \\
\hline $\begin{array}{l}\text { Relations with sup- } \\
\text { pliers and subcon- } \\
\text { tractors }\end{array}$ & $\begin{array}{l}\text { Good financial con- } \\
\text { dition }\end{array}$ & $\begin{array}{l}\text { Social responsibility, } \\
\text { charity activities }\end{array}$ & $\begin{array}{l}\text { Decor of the } \\
\text { registered office and } \\
\text { office interiors } \\
\text { of the company }\end{array}$ \\
\hline $\begin{array}{l}\text { Cooperation with } \\
\text { media }\end{array}$ & The price level & $\begin{array}{l}\text { Name and logo } \\
\text { of the company }\end{array}$ & $\begin{array}{l}\text { Participation in fairs / } \\
\text { exhibitions }\end{array}$ \\
\hline \multirow[t]{4}{*}{ Relations with banks } & The quality of work & & \\
\hline & Timely delivery & & \\
\hline & $\begin{array}{l}\text { Awards and recogni- } \\
\text { tions }\end{array}$ & & \\
\hline & $\begin{array}{l}\text { Lobbying in the local } \\
\text { environment }\end{array}$ & & \\
\hline
\end{tabular}

Source: author's own study based on data obtained from the panel of experts $(n=10)$

An analysis of the carried out systematization indicates that the reputation of a development company has the biggest impact on building its relationship with stakeholders: customers, suppliers and subcontractors, media and banks. In a moderate way reputation affects the experience of the company and its financial condition, prizes and awards received by the company and lobbying in the local environment, as well as features concerning carried out investments: the quality of the workmanship, timely delivery, price level of flats.

Reputation has little or no effect at all on the image factors: name and logo of the company, active advertising policy, social responsibility, charity activities, commercial, decor of the registered office and office interiors of the company and participation in trade fairs/exhibitions.

\section{SUMMARY}

The summary of the results of both types of research, that is the cross-impact method using the MIC-MAC program and the assessment of the individual factors by experts, on the basis of which the key factors in building of reputation were extracted, confirms that the reputation of development enterprises in building their competitive advantage is to the greatest extent influenced by factors related to building relationships with the various stakeholders, the developer's experience, good financial standing, etc.

\section{REFERENCES}

[1] Gotsi M., Wilson M.A., Corporate Reputation: seeking a definition, "Corporate Communitation: An International Journal", vol. 6, no. 1, 2001, p. 29.

[2] The American Heritage Dictionary of the English Language, Fifth Edition, Houghton Mifflin Harcourt Publishing Company 2016, https://www.ahdictionary.com/ word/search.html?q= reputation\&submit. $\mathrm{x}=29 \&$ submit. $\mathrm{y}=13$ [access: 12.12 .2016 ]. 
[3] Wójcicki J.M., Ładyżyński P.: System monitorowania i scenariusze rozwoju technologii medycznych w Polsce, Konsorcjum ROTMED, Warszawa 2008, p. 197.

\section{KLUCZOWE CZYNNIKI KSZTALTOWANIA REPUTACJI W PROCESIE BUDOWANIA PRZEWAGI KONKURENCYJNEJ PRZEDSIEBIORSTW DEWELOPERSKICH - WYNIKI BADAŃ EMPIRYCZNYCH}

W artykule dokonano analizy czynników kształtujących reputację przedsiębiorstw deweloperskich. Tekst stanowi odpowiedź na pytanie, jakie czynniki są istotne w kształtowaniu reputacji $\mathrm{w}$ procesie uzyskiwania przewagi konkurencyjnej przez przedsiębiorstwa deweloperskie. Analizę źródeł wtórnych zweryfikowano wynikami badań empirycznych $\mathrm{w}$ formie panelu ekspertów. Najważniejsze czynniki budowania reputacji wyodrębniono na podstawie ocen ekspertów. Należą do nich: poziom obsługi klienta, dotychczasowa reputacja, wiarygodność przedsiębiorstwa, zaufanie do przedsiębiorstwa, doświadczenie firmy, relacje $\mathrm{z}$ podmiotami otoczenia rynkowego, relacje $\mathrm{z}$ podwykonawcami, bezpieczna sytuacja finansowa (płynność), warunki płatności, poziom cen, koszt jednostkowy produkcji, jakość wykonania robót budowlanych, lokalizacje realizowanych inwestycji, terminowość realizacji, funkcjonalność produktów, zróżnicowanie oferty mieszkaniowej, jakość stosowanych materiałów, zakres i jakość gwarancji, rozpoznawalność marek produktów, rozpoznawalność marki przedsiębiorstwa, kultura organizacyjna, umiejętności kadry kierowniczej dewelopera, fachowość pracowników. Ponadto przeprowadzono analizy metodą cross-impact przy użyciu programu MIC-MAC. Wnioski płynące ze zrealizowanych badań umożliwiły na wyodrębnienie listy najważniejszych czynników kształtowania reputacji w procesie budowania przewagi konkurencyjnej przez deweloperów. Wyniki badań wskazały, że na reputację przedsiębiorstw deweloperskich najsilniej wpływają czynniki dotyczące relacji z klientami oraz dostawcami i podwykonawcami. Reputacja kształtuje się w oparciu o ocene jakości wykonania oraz terminowość realizacji inwestycji, istotne jest doświadczenie firmy oraz prowadzona przez nią aktywna polityka reklamowa. Dokonano także systematyzacji czynników, na które reputacja przedsiębiorstw deweloperskich ma wpływ.

Słowa kluczowe: reputacja, konkurencyjność, przedsiębiorstwa deweloperskie, panel ekspertów, metoda cross-impct.

DOI: $10.7862 /$ rz.2016.mmr.45

Tekst złożono w redakcji: grudzień 2016

Przyjęto do druku: grudzień 2016 